\title{
Melanocytoma of the ciliary body misdiagnosed as iridodialysis
}

This article was published in the following Dove Press journal:

Clinical Ophthalmology

29 May 2014

Number of times this article has been viewed

Moosang Kim
Seung-Jun Lee

Department of Ophthalmology, School of Medicine, Kangwon National University, Chuncheon, Republic of Korea
Correspondence: Seung-Jun Lee Baengnyeong-ro I56, Chuncheon-Si, Gangwon-Do Kangwon National University Hospital 200-722,

Republic of Korea

Tel +823325820I4

Fax +82 29667340

Email kimmoo-79@hanmail.net
Abstract: A 62-year-old female presented to our institution with dimness of vision in her right eye. On examination, her best corrected visual acuity was 20/100 in the right eye. The intraocular pressures were $14 \mathrm{mmHg}$ in both eyes. Slit-lamp examination revealed nuclear sclerotic cataracts bilaterally and iridodialysis in her right eye. Seven days after the first visit, cataract surgery was performed without any complications. One year later, she presented to our institution with acute visual loss and ocular pain in the right eye. Best corrected visual acuity of the right eye was light perception and the intraocular pressure was $44 \mathrm{mmHg}$. Slit-lamp examination revealed a ciliary body mass with widespread pigment dispersion in the anterior segment. Due to no useful vision and uncontrolled pain, enucleation of the right eye was performed. Histopathologic examination revealed a melanocytoma of the ciliary body.

Keywords: ciliary body, iridodialysis, melanocytoma

\section{Introduction}

Although melanocytomas are typically located in the optic nerve head, they can also be found anywhere along the uveal tract, including the iris, choroid, and ciliary body. ${ }^{1-3}$ Melanocytoma is a variant of melanocytic nevi, and its occurrence in the uveal tract is relatively uncommon. In this paper, we report a case of melanocytoma of the ciliary body misdiagnosed as iridodialysis.

\section{Case report}

A 62-year-old female presented to our institution with dimness of vision in the right eye. On examination, her best corrected visual acuity was 20/100 in the right eye and 20/50 in the left eye. Intraocular pressures were $14 \mathrm{mmHg}$ in both eyes. Slit-lamp examination revealed nuclear sclerotic cataracts bilaterally and a small iridodialysis in her right eye. The iridodialysis was within 20 degrees in the 11 o'clock direction, and the iris and its surrounding structures were otherwise unremarkable. However, she had no history of ocular trauma. The pupil was grossly concentric and almost fully dilated after instillation of mydriatics, even though the finding was consistent with the iridodialysis. Fundus examination was unremarkable in both eyes. We considered these findings in the iris as a small asymptomatic dialysis that did not require any specific treatment. The patient wanted surgery for her right eye cataract. Seven days after presentation, the cataract surgery was performed without any complications (Figure 1).

One year later, the patient presented to our institution with acute visual loss and ocular pain in her right eye. Best corrected visual acuity of the right eye was light perception and the intraocular pressure was $44 \mathrm{mmHg}$. Slit-lamp examination and ultrasonography revealed an iridodialysis of nearly 40 degrees and a ciliary body mass with widespread pigment dispersion in the anterior segment (Figure 2). Due to her 

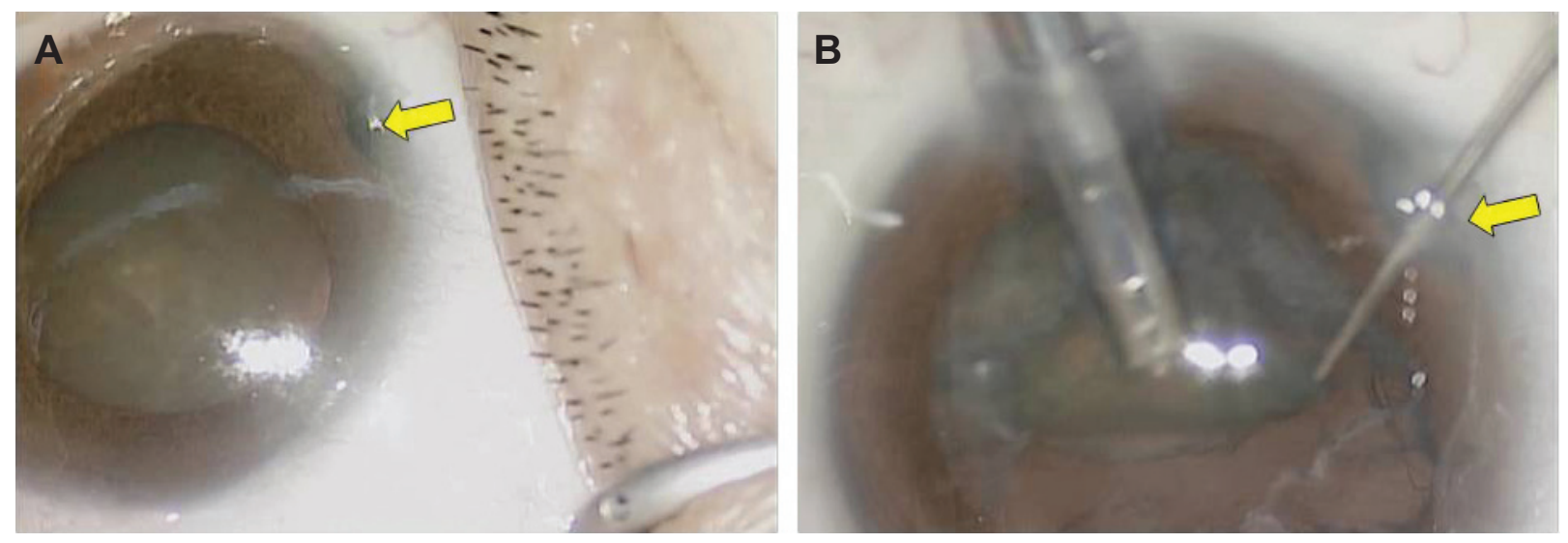

Figure I Views of cataract surgery.

Notes: Before surgery $(\mathbf{A})$ and after phacoemulsification $(\mathbf{B})$. The arrow indicates iridodialysis.

lack of useful vision and her uncontrolled pain, enucleation of the right eye was performed. Histopathologic examination revealed small, round to oval shaped cells with cytoplasm containing abundant melanin pigments, consistent with a melanocytoma. Along with the melanocytoma of the ciliary body, focal malignant transformation with an extension of tumor cells and macrophages into both the trabecular meshwork and anterior chamber angle was noted (Figure 3).

\section{Discussion}

Melanocytoma of the ciliary body is an uncommon tumor of the uveal tract and is generally regarded as benign; it has the ability to invade local tissues, ${ }^{4}$ but has never been shown to metastasize. ${ }^{5}$ Typically it is described at the optic nerve head, ${ }^{1}$ but is encountered less frequently at the ciliary body, ${ }^{6}$ and there are rare reports of occurrence in the iris, ${ }^{7}$ sclera, ${ }^{8}$ conjunctiva, ${ }^{9}$ and choroid. ${ }^{10,11}$

Melanocytoma of the ciliary body is often clinically undetected until it extends into the pupil, anterior chamber, or sclera, since it is hidden by the iris. Seeding of tumor cells on the iris, pigment dispersion from necrosis, elevated intraocular pressure, extrascleral extension, change in refractive error with increasing astigmatism, or cataract from compression are other telltale signs. These findings may be suggestive of a malignant change in the tumor. ${ }^{12-14}$

Anatomically speaking, iridodialysis is a separation between the iris root and the ciliary body. It is usually caused by blunt or penetrating trauma, or by an iatrogenic complication of intraocular surgery. Since it rarely occurs for reasons other than direct trauma, a thorough search for etiologies that could have caused structural changes in the iris or ciliary body is recommended. In this case, we found that the iridodialysis was widened, with widespread pigment dispersion into the surrounding structures, which had not been detectable at the initial examination.

A spontaneous iridodialysis and ongoing anatomic changes could indicate a neoplasm of an angle structure origin, which is difficult to identify clinically. Early detection of such a neoplasm increases the chance of preserving the eyeball and vision by various methods, including an
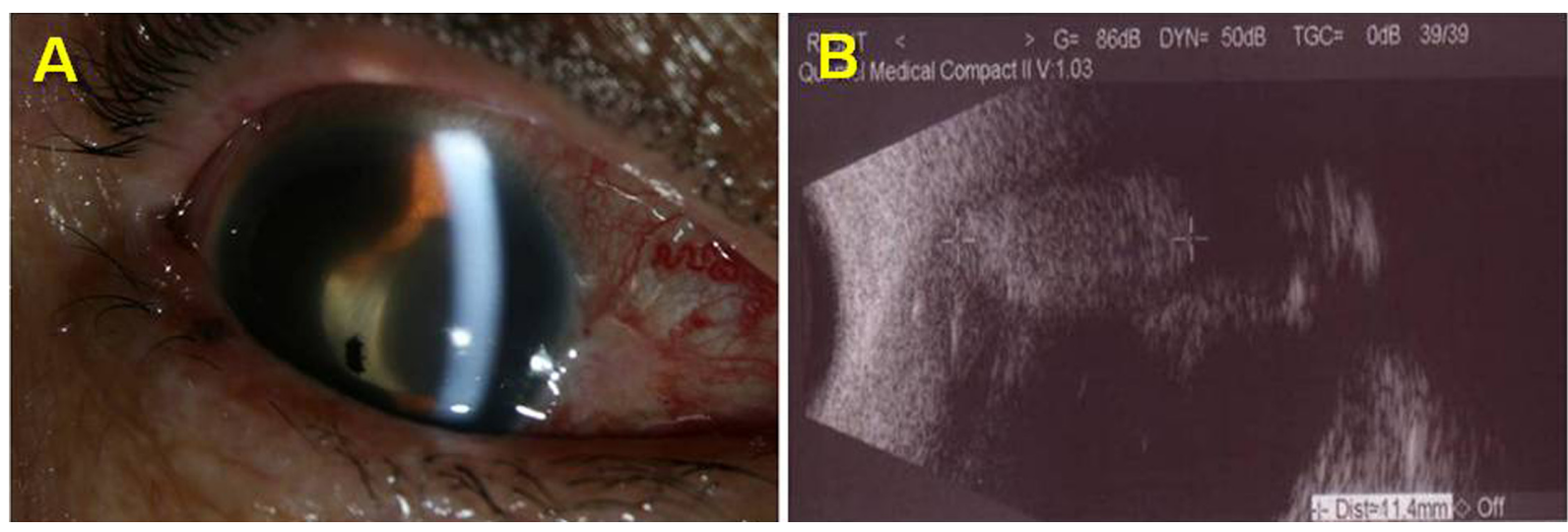

Figure 2 Anterior segment photograph and ultrasonographic findings.

Notes: Pigment dispersion in anterior chamber $(\mathbf{A})$ and ciliary body mass $(\mathbf{B})$. 

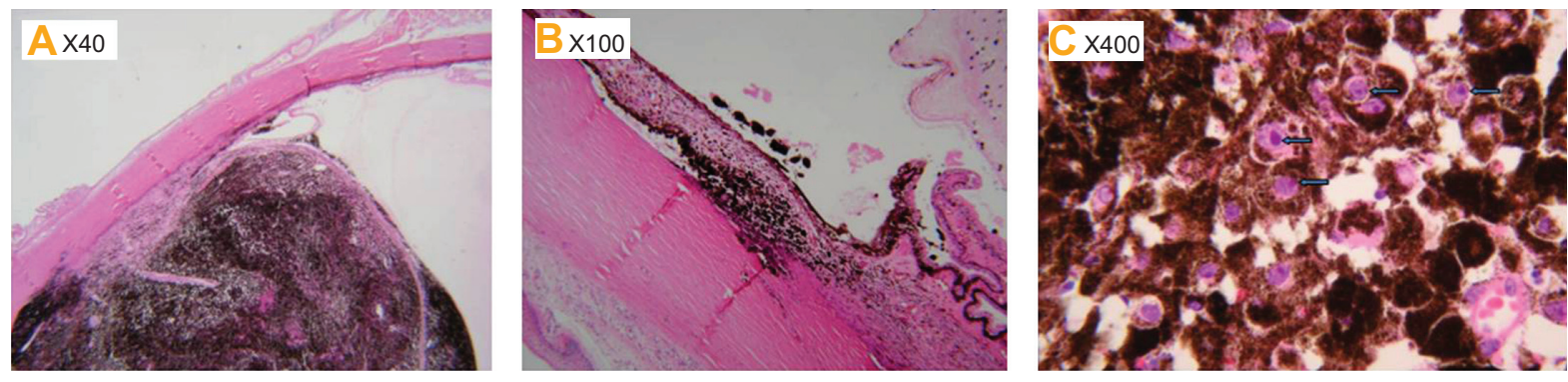

Figure 3 Light microscopy views.

Notes: (A) A pigmented mass in the ciliary body (40x), (B) involvement of trabecular meshwork by the tumor cells (I00x), and (C) round to oval bland cytologic features of tumor cells (400x). They show prominent nucleoli (arrows) and marked cytoplasmic melanin pigments.

en bloc resection. ${ }^{15}$ If a spontaneous iridodialysis with no plausible explanation is encountered, an early and thorough search should be done in the anterior chamber angle, including gonioscopy or anterior segment optical coherence tomography. In summary, melanocytoma of the ciliary body is a rare tumor, is clinically hard to detect, and can invade chamber angle structures and appear as a pigmented mass at the iris root.

\section{Conclusion}

This is a case of melanocytoma of the ciliary body misdiagnosed as iridodialysis. A physician should always keep in mind that a careful evaluation of the anterior chamber angle (eg, gonioscopy, anterior segment optical coherence tomography) is the most important step for making an accurate diagnosis.

\section{Disclosure}

The authors report no conflicts of interest in this work.

\section{References}

1. Demirci H, Mashayekhi A, Shields CL, Eagle RC Jr, Shields JA. Iris melanocytoma: clinical features and natural course in 47 cases. Am J Ophthalmol. 2005;139(3):468-475.

2. Brownstein S, Dorey MW, Mathew B, Little JM, Lindley JI. Melanocytoma of the choroid: atypical presentation and review of the literature. Can J Ophthalmol. 2002;37(4):247-252.
3. Shields JA, Shields CL, Eagle RC Jr. Melanocytoma (hyperpigmented magnocellular nevus) of the uveal tract: the 34th G. Victor Simpson lecture. Retina. 2007;27(6):730-739.

4. Zimmerman LE. Melanocytes, melanocytic nevi and melanocytomas. Invest Ophthalmol. 1965;4:11-41.

5. Raichand M, Peyman GA, Juarez CP, Seetner AA, Sugar J, Goldberg MF Resection of uveal melanocytoma: clinicopathological correlation. Br J Ophthalmol. 1983;67(4):236-243.

6. Shammas HJ, Minckler DS, Hulquist R, et al. Melanocytoma of the ciliary body. Ann Ophthalmol. 1981;13:1381-1383.

7. Shields JA, Augsburger JJ, Bernardino V Jr, Eller AW, Kulczycki E. Melanocytoma of the ciliary body and iris. Am J Ophthalmol. 1980; 89(5):632-635.

8. Lee JS, Smith RE, Minckler DS. Scleral melanocytoma. Ophthalmology. 1982;89(2):178-182.

9. Verdaguer J, Valenzuela H, Strozzi L. Melanocytoma of the conjunctiva. Arch Ophthalmol. 1974;91(5):363-366.

10. Shields JA, Font RL. Melanocytoma of the choroid clinically simulating a malignant melanoma. Arch Ophthalmol. 1972;87:396-400.

11. Jürgens I, Roca G, Sedó S, Pujol O, Berniell JA, Quintana M. Presumed melanocytoma of the macula. Arch Ophthalmol. 1994;112(3): 305-306.

12. Bhorade AM, Edward DP, Goldstein DA. Ciliary body melanocytoma with anterior segment pigment dispersion and elevated intraocular pressure. J Glaucoma. 1999;8(2):129-133.

13. Cialdini AP, Sahel JA, Jalkh AE, Weiter JJ, Zakka K, Albert DM. Malignant transformation of an iris melanocytoma. A case report. Graefes Arch Clin Exp Ophthalmol. 1989;227(4):348-354.

14. Radcliffe NM, Finger PT. Eye cancer related glaucoma: current concepts. Surv Ophthalmol. 2009;54(1):47-73.

15. Weinstein GW, Quayle WH. An en bloc technique for the resection of anterior uveal tumors. Am J Ophthalmol. 1979;88(3 Pt 1):519-523.
Clinical Ophthalmology

\section{Publish your work in this journal}

Clinical Ophthalmology is an international, peer-reviewed journal covering all subspecialties within ophthalmology. Key topics include: Optometry; Visual science; Pharmacology and drug therapy in eye diseases; Basic Sciences; Primary and Secondary eye care; Patient Safety and Quality of Care Improvements. This journal is indexed on
PubMed Central and CAS, and is the official journal of The Society of Clinical Ophthalmology (SCO). The manuscript management system is completely online and includes a very quick and fair peer-review system, which is all easy to use. Visit http://www.dovepress.com/ testimonials.php to read real quotes from published authors. 